\title{
PENGARUH BAHAN TAMBAH FLY ASH \\ TERHADAP KARAKTERISTIK TANAH LEMPUNG EKSPANSIF DI DAERAH DRINGU KABUPATEN PROBOLINGGO
}

\author{
THE EFFECT OF ADDED FLY ASH \\ AGAINTS EXPENSIVE CLAY SOIL CHARACTERISTICS \\ AT DRINGU DISTRICT PROBOLINGGO
}

\author{
Ernawan Setyono $^{1}$, Sunarto $^{2}$, Kukuh Wirasetiyo ${ }^{3}$ \\ 1,2,3 Jurusan Teknik Sipil FT-UMM \\ Jalan Raya Tlogomas 246 Malang 65144 Tlp. (0341) 464318-319 Pes. 130 Fax. (0341)460435 \\ Alamat korespondensi: \\ Kukuh.wirasetiyo@gmail.com
}

\begin{abstract}
The soil is useful as a building material on various jobs, in addition to the soil functions as well as supporting the foundation of the building and the road. This problem can be solved by retrofitting efforts on problematic soils that have good carrying capacity and ability to maintain volume changes during the service period despite differences in field conditions and soil types. The research to be conducted is stabilization of expansive clay soil by using added fly ash material with CBR mechanical parameters and unconfined compressive strength. The results of the effects of the added fly ash material on expansive clay soil characteristics are decreased from the soil consistency limit test such as LL, PL and PI. Then for CBR and Unconfined Compressive Strength with mixed variations of $0 \%$ to $20 \%$ continue to increase until reaching the peak point on the percentage of $17.5 \%$ with the value of CBR $20.63 \%$ and Unconfined Compressive Strength of $0.53 \mathrm{~kg} / \mathrm{cm} 2$, while at the percentage $20 \%$ decreased with the value of CBR 19.42\% and Unconfined Compressive Strength 0,525 kg / cm2.
\end{abstract}

Keywords : Fly Ash, Soil Expansive, Stabilization

\begin{abstract}
Abstrak
Tanah berguna sebagai bahan bangunan pada berbagai macam pekerjaan, di samping itu tanah berfungsi juga sebagai pendukung pondasi dari bangunan maupun jalan. Permasalahan ini dapat diatasi dengan usaha-usaha perkuatan yang di lakukan pada tanah yang bermasalah sehingga mempunyai daya dukung yang baik dan berkemampuan mempertahankan perubahan volume selama masa pelayanan walaupun terdapat perbedaan kondisi lapangan dan jenis tanah. Penelitian yang akan dilakukan adalah stabilisasi tanah lempung ekspansif dengan menggunakan bahan tambah fly ash dengan parameter mekanis CBR dan Kuat tekan bebas. Hasil penelitian dari pengaruh bahan tambah fly ash terhadap karakteristik tanah lempung ekspansif ialah mengalami penurunan dari uji batas konsistensi tanah seperti LL,PL dan PI. Kemudian untuk CBR dan Kuat Tekan Bebas dengan variasi campuran 0\% sampai dengan $20 \%$ terus meningkat hingga mencapai titik puncak pada persentase $17,5 \%$ dengan nilai CBR $20,63 \%$ dan Kuat Tekan Bebas sebesar $0,53 \mathrm{~kg} / \mathrm{cm}^{2}$, sedangkan pada persentase $20 \%$ menurun dengan nilai CBR 19,42\% dan Kuat Tekan Bebas 0,525 kg/cm².
\end{abstract}

Kata Kunci : Fly Ash, Stabilisasi,Tanah Ekspansif

\section{PENDAHULUAN}

Tanah berguna sebagai bahan bangunan pada berbagai macam pekerjaan, di samping itu tanah berfungsi juga sebagai pendukung pondasi dari bangunan maupun jalan . Tanah juga berperan penting dalam penentuan tebal perkerasan jalan. Lapisan ini harus cukup kuat, mempunyai CBR 20\% dan plastisitas Indeks $(\mathrm{PI})<10 \%$

(Sukirman,1992).
Jika tanah asli mempunyai daya dukung rendah, maka konstruksi jalan akan cepat mengalami kerusakan.Adapun jika jenis tanah yang digunakan pada jalan merupakan tanah yang tidak stabil atau tanah bermasalah. Maka kriteria yang dipakai untuk menilai memuaskan atau tidaknya stabilisasi, didasarkan faktor kekuatan dengan menggunakan parameter CBR. 
Adapun cara sederhana yang dapat digunakan yaitu dengan cara pemadatan, namun dengan kondisi tanah dasar yang memiliki kestabilan dengan nilai CBR (California Bearing Ratio) yang tinggi seperti yang disyaratkan dalam suatu konstruksi jalan. Tapi apabila kita hadapkan pada kondisi lapangan dengan kondisi tanah dasar yang bermasalah atau kurang mendukung untuk suatu konstruksi jalan, maka selain pemadatan diperlukan juga perlakuan khusus, diantaranya dengan menggunakan bahan tambahan (additive) untuk perbaikan tanah tersebut.

Pada penelitian ini ada beberapa rumusan masalah yaitu bagaimana pengaruh tanah lempung ekspansif setelah di stabilisasi dengan bahan additive fly ash. Kemudian Bagaimana Berapa besarnya perbandingan prosentase penambahan Fly Ash sehingga di dapatkan kondisi yang memenuhi syarat terhadap tanah lempung ekspansif sebagai lapisan pondasi dasar jalan. Adapun tujuan dari penelitian ini adalah untuk mengetahui berapa prosentase kondisi yang memenuhi syarat dari Fly Ash terhadap tanah lempung ekspansif dalam hal peningkatan parameter fisis dan mekanis tanah. Serta untuk mengetahui pengaruh penambahan Fly Ash terhadap nilai CBR dan kuat tekan tanah.

\section{Tanah}

Tanah dasar yang baik untuk konstruksi perkerasan jalan adalah tanah dasar yang telah dipadatkan sampai tingkat kepadatan tertentu sehingga mempunyai daya dukung yang baik serta berkemampuan mempertahankan perubahan volume selama masa pelayanan walaupun terdapat perbedaan kondisi lingkungan dan jenis tanah setempat. (Hardiyatmo,2010).Untuk mengetahui sifat tanah dapat dilihat dari nilai indeks plastisitas (IP), yang disajikan pada Tabel 1

Tabel 1 Nilai Indeks Plastisitas dan Macam Tanah (Jumikis,1992)

\begin{tabular}{|c|c|c|c|}
\hline \multirow[b]{2}{*}{ PI } & \multicolumn{3}{|c|}{ Macam } \\
\hline & Sifat & Tanah & Kohesi \\
\hline 0 & $\begin{array}{l}\text { Non Plastis } \\
\text { Plastisitas }\end{array}$ & Pasir & $\begin{array}{l}\text { Non Kohesif } \\
\text { Kohesif }\end{array}$ \\
\hline$<7$ & $\begin{array}{l}\text { Rendah } \\
\text { Plastisitas }\end{array}$ & $\begin{array}{l}\text { Lanau } \\
\text { Lempung }\end{array}$ & Sebagian \\
\hline $7-17$ & $\begin{array}{l}\text { Sedang } \\
\text { Plastisitas }\end{array}$ & Berlanau & Kohesif \\
\hline$>17$ & Tinggi & Lempung & Kohesif \\
\hline
\end{tabular}

(Sumber : Hardiyatmo,2010)
Daya dukung tanah dasar dapat diperkirakan dengan mempergunakan hasil klasifikasi ataupun pemeriksaan CBR (California Bearing Ratio).Nilai daya dukung pada lapisan konstruksi perkerasan jalan, perkerasan jalan sendiri terdiri dari beberapa lapisan antara lain lapis penutup atau lapis aus, perkerasan dan tanah dasar masing-masing mempunyai ketebalan yang berbeda. Tebalnya lapis perkerasan (pondasi perkerasan jalan) sangat terpengaruh oleh besarnya nilai daya dukung tanah dasar atau subgrade yaitu nilai CBR nya. (Sukirman 1992)

Sifat mengembang dan menyusut dari tanah tertentu akibat perubahan kadar air. Hal ini dapat dikurangi dengan memadatkan tanah pada kadar air optimum sehingga mencapai kepadatan tertentu sehingga perubahan volume yang mungkin terjadi dapat dikurangi. Kondisi drainase yang baik dapat menjaga kemungkinan berubahnya kadar air pada lapisan tanah dasar.

Daya dukung yang tidak merata akibat pelaksanaan yang kurang baik. Hal ini akan lebih jelek pada tanah dasar dari jenis tanah berbutir kasar dengn adanya tambahan pemadatan akibat pembebanan lalu lintas ataupun akibat berat tanah dasar itu sendiri (pada tanah dasar tanah timbunan). Hal ini dapat diatasi dengan melakukan pengawasan yang baik pada saat pelaksanaan pekerjaan tanah dasar.

Umumnya, penentuan sifat-sifat tanah banyak di jumpai dalam masalah teknis yang berhubungan dengan tanah. Dalam banayak masalah teknis (semacam perencanaan perkerasan jalan, bendungan dalam urugan, dan lain-lainnya), pemilihan tanah-tanah ke dalam kelompok ataupun subkelompok yang menunjukkan sifat atau kelakuan yang sama akan sangat membantu pemilihan ini disebut klasifikasi. Klasifikasi tanah sangat membantu peran dalam memberikan pengarahan melalui cara empiris yang tersedia dari hasil pengalaman yang telah lalu. Tetapi, perancang harus berhati-hati dalam penerapannya karena penyelesaian masalah stabilitas, kompresi (penurunan), aliran air yang didasarkan pada klasifikasi tanah sering menimbulkan kesalahan yang berarti. (Hardiyatmo, 2010). 


\section{Tanah Lempung Ekspansif}

Tanah ekspansif merupakan salah satu jenis yang sering bermasalah bagi konstruksi yang berada di atas tanah ini. Tanah ini akan mengalami perubahan volume akibat fluktuasi kadar air, perilakunya akan mengembang ketika kondisi tanah basah dan akan menyusut ketika kondisi tanah kering, sehingga tanah ini sering disebut tanah kembang susut atau tanah bergerak. Pengembangan dan penyusutan tanah ekspansif berdampak terhadap kerusakan bangunan dan jalan raya. Kerusakan bangunan ringan yang terjadi retak-retak pada dinding dan lantai hingga pondasi, sedangkan pada jalan raya mulai retak memanjang hingga retak longitudinal. (Sudjianto,2014)

\section{Fly Ash}

Fly Ash atau abu terbang adalah material yang sangat halus yang didapat dari akibat sisa pembakaran batu bara. Seperti halnya kapur dan semen, Fly Ash juga dapat digunakan sebagai stabilisasi tanah dan mengurangi potensi perubahan volume tanah. Fly Ash dapat digunakan untuk memodifikasi tanah maupun mempercepat pembentukan kekuatan tanah yang kurang stabil dan keuntungan penggunaan Fly Ash sebagai bahan stabilisasi tanah adalah untuk memanfaatkan material hasil buangan pabrik dan harganya lebih murah dibandingkan dengan stabilisasi kapur maupun semen (Hardiyatmo, 2014).

\section{CBR (California Bearing Ratio)}

Pengujian ini dilakukan dengan berpedoman terhadap standard percobaan AASHTO T 193 - 74.Daya dukung tanah dasar (subgrade) pada perencanaan perkerasan lentur dinyatakan dengan nilai CBR (California Bearing Ratio). CBR untuk pertama kalinya diperkenalkan oleh California Division of Highways pada tahun 1928. Sedangkan metode CBR ini di populerkan oleh O.J. Porter. CBR dipergunakan untuk menilai kekuatan tanah dasar atau bahan lain yang hendak dipakai untuk pembuatan perkerasan (Sukirman, 1995).

Jadi nilai CBR didefinisikan sebagai suatu perbandingan antara beban percobaan (test load) dengan beban standar (standartd load) dan dinyatakan dalam prosentase. Tujuan dari percobaan CBR adalah untuk menentukan daya dukung tanah dalam kepadatan maksimum. Harga CBR adalah nilai yang menyatakan kualitas tanah dasar dibandingkan dengan bahan standar berupa batu pecah yang mempunyai nilai CBR sebesar $100 \%$ dalam memikul beban lalu lintas. Hasil pengujian CBR ini dapat diperoleh dengan mengukur besarnya beban pada penetrasi tertentu. Besarnya penetrasi sebagai dasar menentukan CBR adalah penetrasi 0,1 " dan 0,2 ". Berikut klasifikasi tanah berdasarkan CBR, pada Tabel 2.

Tabel 2 Klasfikasi Tanah Berdasarkan CBR

\begin{tabular}{ccc} 
CBR & General Rating & Uses \\
\hline $0-3$ & Very poor & Subgrade \\
$3-7$ & Poor to fair & Subgrade \\
$7-20$ & Fair & Subbase \\
$20-50$ & Good & Base, subbase \\
$>50$ & Excellent & Base, subbase \\
\hline \multicolumn{2}{c}{ (Sumber : Braja M.Das.(1995)) }
\end{tabular}

\section{Kuat Tekan Bebas}

Pemeriksaan ini di maksudkan untuk menentukan besarnya kekuatan tekan bebas contoh tanah berbentuk silinder yang bersifat kohesif dalam keadaan asli (undisturbed) maupun tidak asli (Compacted or remoulded).

Mode pengujian ini meliputi penentuan nilai kuat tekan bebas (Unconifined compressive strength) - qu untuk tanah kohesif dari benda uji asli (undisturbed) maupun buatan (remoulded or recompated samples). Yang dimaksud dengan kuat tekan bebas (qu) adalah besarnya beban aksial persatuan luas pada saat benda uji mengalami keruntuhan (beban maksmimum), atau apabila regangan aksial telah mencapai $15 \%$. Nilai qu yang diperoleh dari pengujian ini dapat digunakan untuk menentukan konsistensi dari tanah lempung, seperti ditunjukan pada Tabel 3. 
Tabel 3 Parameter Konsistensi Tanah

\begin{tabular}{ll}
\multicolumn{1}{c}{$\sigma\left(\mathrm{kg} / \mathrm{cm}^{2}\right)$} & \multicolumn{1}{c}{ Konsistensi } \\
\hline$<0,24$ & Very soft \\
$0,24-0,48$ & Soft \\
$0,48-0,96$ & Medium Soft \\
$0,96-1,92$ & Stiff \\
$1,92-3,83$ & Very Stif \\
$>3,83$ & Hard
\end{tabular}

Selain itu, melalui pengujian ini dapat ditentukan nilai kepekaan (sensifity) dari tanah kohesif, yaitu perbandingan antara qu tanah asli terhadap qu tanah buatan. Pengujian kuat tekan bebas pada dasarnya merupakan keadaan yang khusus pada percobaan triaksial, dimana tegangan sel (confining pressure) $-\sigma 3$, besarnya sama dengan nol. Dengan demikian dapat pula ditentukan nilai kohesi (c) dalam konsep tegangan total (total preassure), yaitu sebesar $1 / 2$ dari nilai qu.

\section{METODE PENELITIAN}

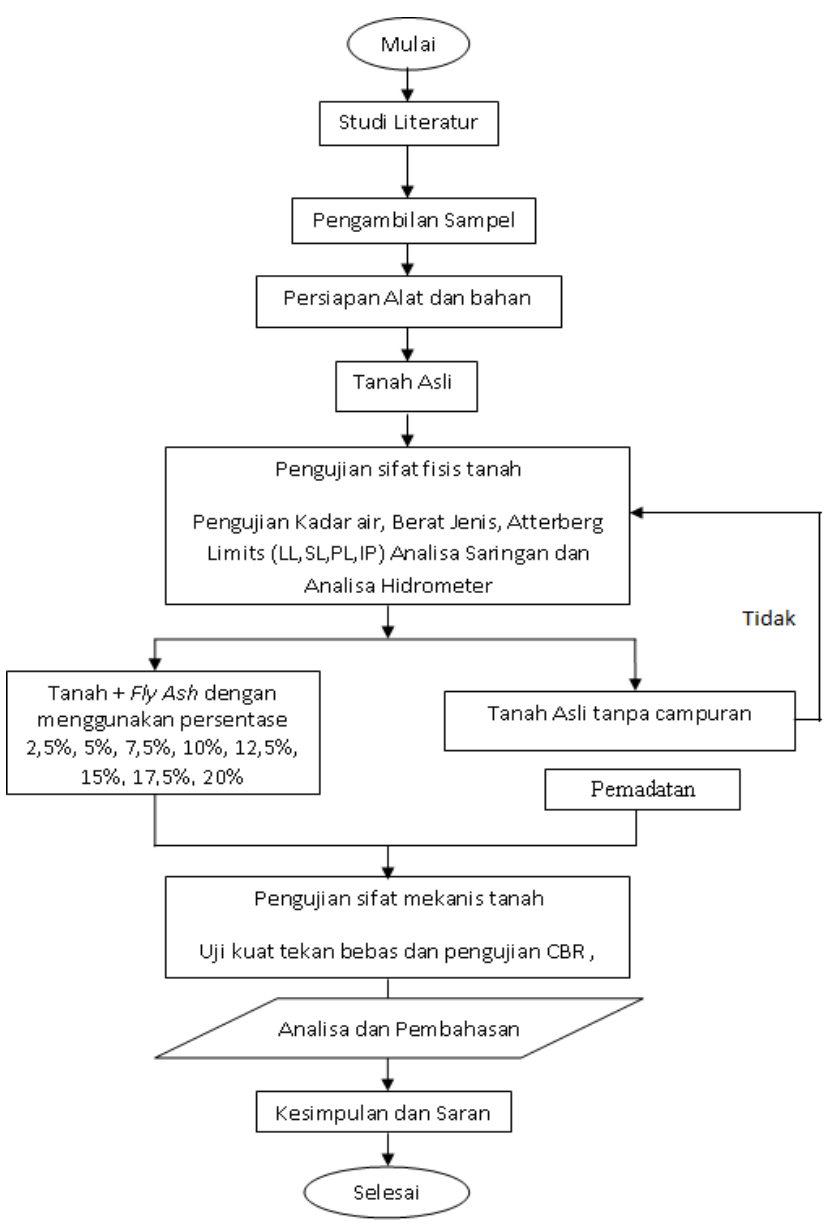

Gambar 1. Diagram Alir Penelitian

\section{HASIL DAN PEMBAHASAN \\ Pengujian Kadar Air Tanah}

Pada tanah dalam keadaan aslinya kadar air besarnya dari 15\% - 100\%. Hasil dari pengujian kadar air tanah lempung ekspansif tanpa campuran didapatkan dengan kadar air rata rata sebesar $22,61 \%$.

\section{Pemeriksaan Berat Jenis}

Pemeriksaan ini dimaksudkan untuk menentukan berat jenis tanah yang mempunyai butiran lewat saringan No.4 dengan piknometer.

Hasil dari pemeriksaan berat jenis tanah pada penelitian ini di dapatkan hasil rata-rata dari perbandingan antara berat bahan dengan berat air yang isinya sama, yaitu sebesar 2,69 .

\section{Analisa Saringan}

Pengujian berat jenis tanah (specific gravity) adalah perbandingan anatara berat butir tanah dengan volume butir, pada tempratur tertentu.Tujuan dari melakukan pemeriksaan ini yaitu untuk menentukan pembagian ukuran butiran suatu contoh tanah.

Dari hasil analisis gradasi diperoleh butiran tanah yang lolos no.saringan 10 sebanyak $11,57 \%$, untuk no.saringan 40 sebanyak $2,43 \%$, sedangkan untuk saringan no.200 sebanyak $0,27 \%$. Hasil ini di dapat dari tanah asli yang di ambil dari tempat lokasi dan langsung dilakukan pemeriksaan analisa saringan tanpa melakukan penghalusan terlebih dahulu.

\section{Atterberg Limit}

Pengujian batas konsistensi (Atterberg Limit), pengujian ini dilakukan dengan berpedoman terhadap Standard Percobaan AASHTO T 89-74. Penelitian ini dilakukan untuk mengeahui batas cair, batas susut, batas plastis dan indeks plastisitas dari suatu tanah. Hasil yang didapat pemeriksaan atterberg ini di tunjukkan dari data yang telah di peroleh bahwa tanah ekspansif dengan bahan tambah fly ash $0 \%, 2,5 \%, 5 \%, 7,5 \%$, $10 \%, 12,5 \%, 15 \%, 17,5 \%, 20 \%$ ini memiliki peran penting dalam menstabilkan tanah lempung ekspansif ini. Di buktikan bahwa pada setiap penambahan bahan tambah nilai LL, PL, dan PI mengalami penurunan hingga di katakan bahwa plastisitas rendah $(<17 \%)$ pada porsentase $20 \%$, berikut Tabel 4 . 
Tabel 4 Hasil Atterberg Limit

\begin{tabular}{lccc}
\hline \multicolumn{1}{c}{$\begin{array}{c}\text { Jenis tanah + } \\
\text { Bahan Additive }\end{array}$} & \multicolumn{3}{c}{ Batas Atterberg } \\
\cline { 2 - 4 } Cair & $\begin{array}{c}\text { Batas } \\
\text { Plastis }\end{array}$ & $\begin{array}{c}\text { Indeks } \\
\text { Plastisitas }\end{array}$ \\
\hline $\begin{array}{l}\text { Lempung Ekspansif } \\
\text { + FA 0\% }\end{array}$ & 66.00 & 38.13 & 27.87 \\
$\begin{array}{l}\text { Lempung Ekspansif } \\
\text { + FA 2,5\% }\end{array}$ & 62.00 & 37.01 & 24.99 \\
$\begin{array}{l}\text { Lempung Ekspansif } \\
\text { + FA 5\% }\end{array}$ & 59.50 & 36.57 & 22.93 \\
$\begin{array}{l}\text { Lempung Ekspansif } \\
\text { + FA 7,5\% }\end{array}$ & 35.20 & 14.31 & 20.89 \\
$\begin{array}{l}\text { Lempung Ekspansif } \\
\text { + FA 10\% }\end{array}$ & 31.20 & 12.16 & 19.04 \\
$\begin{array}{l}\text { Lempung Ekspansif } \\
\text { + FA 12,5\% }\end{array}$ & 27.60 & 11.13 & 16.47 \\
$\begin{array}{l}\text { Lempung Ekspansif } \\
\text { + FA 15\% }\end{array}$ & 20.40 & 9.61 & 10.79 \\
$\begin{array}{l}\text { Lempung Ekspansif } \\
\text { + FA 17.5\% }\end{array}$ & 20.00 & 10.39 & 9.61 \\
$\begin{array}{l}\text { Lempung Ekspansif } \\
\text { + FA 20\% }\end{array}$ & 16.58 & 9.61 & 6.97 \\
\hline
\end{tabular}

\section{Pemeriksaan CBR}

Pembuatan benda uji CBR Fly Ash 0\% sampai dengan Fly Ash 20\% dilakukan pada tanggal 27 Desember 2016 sampai dengan 23 Januari 2017 dan langsung dilakukan perendaman selama 3 hari pada saat benda uji telah selesai dibuat kemudian dilakukan pengujian. Sebelum pembuatan benda uji dilakukan penambahan kadar air sesuai dengan hasil yang telah didapat dari kadar air optimum pada pemeriksaan pemadatanBerikut hasil pengujian benda uji CBR dengan menggunakan variasi bahan tambah Fly ash $0 \%$ sampai dengan 20\%, berikut hasil penelitian CBR pada Tabel 5 .

Tabel 5 Hasil CBR (Fly Ash 0\% - 20\%)

\begin{tabular}{ccc}
\hline Variasi Campuran & CBR 0.1" & CBR 0.2" \\
\hline $\begin{array}{c}\text { Tanah Ekspansif + FA 0\% } \\
\text { Tanah Ekspansif + FA }\end{array}$ & $8.49 \%$ & $7.55 \%$ \\
Tanah Ekspansif + FA 5\% & $10.32 \%$ & $9.89 \%$ \\
Tanah Ekspansif + FA & $12.14 \%$ & $12.00 \%$ \\
$7,5 \%$ & $13.96 \%$ & $12.68 \%$ \\
Tanah Ekspansif + FA 10\% & $15.78 \%$ & $14.43 \%$ \\
Tanah Ekspansif + FA & $18.20 \%$ & $16.32 \%$ \\
$\begin{array}{c}\text { 12,5\% } \\
\text { Tanah Ekspansif + FA 15\% } \\
\text { Tanah Ekspansif + FA } \\
17,5 \%\end{array}$ & $20.23 \%$ & $20.10 \%$ \\
Tanah Ekspansif + FA 20\% & $19.42 \%$ & $18.07 \%$ \\
\hline
\end{tabular}

Dari tabel di atas dijelaskan bahwa pengujian CBR dengan menggunakan persentase $0 \%$ sampai dengan 20\% terus mengalami peningkatan hingga mencapai titik puncak pada persentase $17,5 \%$ dengan nilai CBR sebesar $20,63 \%$ dan mengalami penurunan pada persentase $20 \%$ dengan nilai CBR sebesar 19,42\%. Disimpulkan bahwa stabilisasi tanah dengan bahan tambah fly ash $17,5 \%$ dapat dikatakan baik untuk digunakan sebagai perkerasan jalan, ditunjukkan pada Gambar 2.

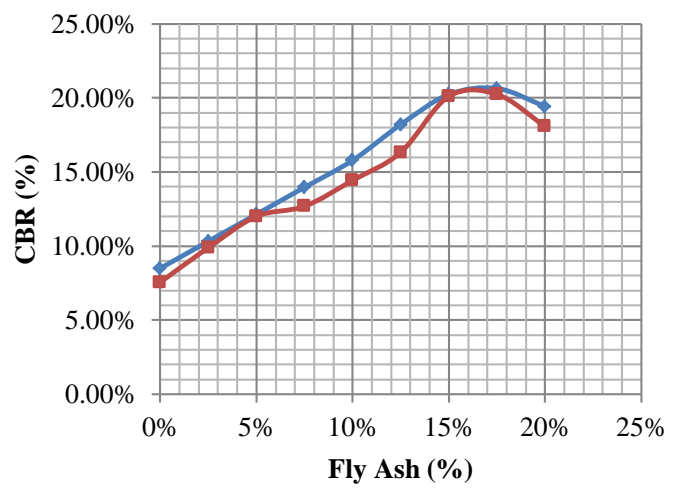

Gambar 2. Grafik CBR 0,1" dan 0,2" (Fly Ash 0\% - 20\%)

\section{Pemeriksaan Kuat Tekan Bebas}

Berikut hasil pemeriksaan benda uji pada pengujian Kuat Tekan Bebas dengan variasi bahan tambah fly ash $0 \%$ sampai dengan $20 \%$ dapat di lihat pada Tabel 6 .

Tabel 6 Data Hasil Pengujian Kuat Tekan Bebas

\begin{tabular}{|c|c|c|}
\hline Variasi Campran & $\begin{array}{c}\mathrm{qu} \\
\left(\mathrm{Kg} / \mathrm{cm}^{2}\right)\end{array}$ & $\begin{array}{c}\text { Strain } \\
(\%)\end{array}$ \\
\hline Lempung Ekspansif + FA 0\% & 0.32 & 10.8 \\
\hline $\begin{array}{c}\text { Lempung Ekspansif + FA } \\
2,5 \%\end{array}$ & 0.36 & 10.8 \\
\hline Lempung Ekspansif + FA 5\% & 0.39 & 10.8 \\
\hline $\begin{array}{c}\text { Lempung Ekspansif + FA } \\
7,5 \%\end{array}$ & 0.42 & 11 \\
\hline Lempung Ekspansif + FA 10\% & 0.45 & 11 \\
\hline $\begin{array}{c}\text { Lempung Ekspansif + FA } \\
12,5 \%\end{array}$ & 0.48 & 11.1 \\
\hline Lempung Ekspansif + FA 15\% & 0.51 & 11.8 \\
\hline $\begin{array}{c}\text { Lempung Ekspansif + FA } \\
17,5 \%\end{array}$ & 0.53 & 11.1 \\
\hline Lempung Ekspansif + FA $20 \%$ & 0.525 & 10.4 \\
\hline
\end{tabular}

Dari tabel dijelaskan bahwa pengujian Kuat Tekan Bebas dengan menggunakan persentase $0 \%$ sampai dengan 20\% terus mengalami peningkatan hingga mencapai titik puncak pada persentase $17,5 \%$ dengan nilai tegangan (qu) sebesar $0,53 \mathrm{~kg} / \mathrm{cm}^{2}$ dan 
mengalami penurunan pada persentase $20 \%$ dengan nilai tegangan (qu) sebesar 0,525 $\mathrm{kg} / \mathrm{cm}^{2}$. Berikut merupakan grafik kuat tekan bebas, di tujukan pada Gambar 3.

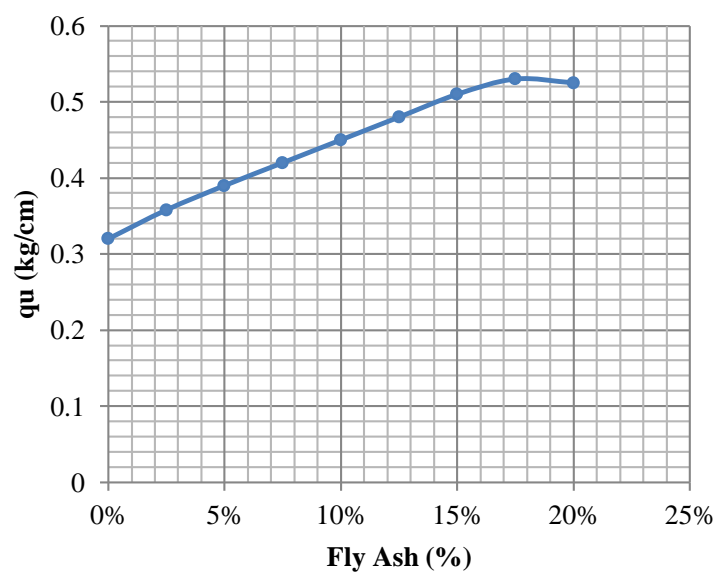

Gambar 3. Grafik Kuat Tekan Bebas (qu) (Fly Ash 0\% - 20\%)

\section{KESIMPULAN}

- Hasil uji batas konsistensi (batas-batas atterberg limits) campuran tanah dengan penambahan persentase fly ash di bandingkan tanah asli menunjukan batas cair (LL) mengalami penurunan dan batas plastis (PL) cenderung menurun, maka Indeks Plastisitasnya (IP) pun menurun. Untuk nilai CBR cenderung meningkat dan mencapai titik puncak peningkatan pada penambahan fly ash $17,5 \%$ sebesar $20,63 \%$ tetapi pada penambahan $20 \%$ mengalami penurunan menjadi $19,42 \%$. Sedangkan pada nilai kuat tekan bebas pun sama cenderung terus meningkat dan mencapai titik puncak pada penambahan $17,5 \%$ sebesar $0.53 \mathrm{~kg} / \mathrm{cm}^{2}$ dan pada penambahan $20 \%$ mengalami penurunan menjadi $0.525 \mathrm{~kg} / \mathrm{cm}^{2}$.

- Dari hasil penelitian dari pengujian di Laboratorium yang telah dilakukan, bahwa lempung ekspansif tersebut dapat dijadikan sebagai lapisan pondasi dasar (subgrade) jalan apabila di stabilisasi dengan bahan additive fly ash. Dengan persentase penambahan fly ash maksimum $17,5 \%$ hal ini dapat dilihat dari peningkatan nilai CBR tanah.

\section{DAFTAR PUSTAKA}

DAS, B.M., 1988, Mekanika Tanah (Prinsipprinsip Rekayasa Geoteknis), Jilid 1, Surabaya.
Hardiyatmo, C., 2010. Mekanika Tanah 1, Edisi kelima, Yogyakarta.

Hardiyatmo, C., 2010. Stabilasasi Tanah Untuk Perkerasan Jalan, Yogyakarta

Sudjianto, A.T., 2014. Tanah Ekspansif, Malang.

Sukirman, S., 1999, Perkerasan Lentur Jalan Raya, Bandung. 